\title{
Introduction: Centring Animals Within Medical History
}

In a recent handbook on the history of medicine, authors Robert Kirk and Michael Worboys argued that 'In no body of scholarship is it more obvious, puzzling and true to say that "animals disappear." ' Literally, of course, this is not the case, for as Etienne Benson points out,

to a limited but important extent, writing about human history is alwaysalready writing about animals ... Humans are a kind of animal that (like all kinds of animal) has been and continues to be profoundly reshaped by its interactions with other kinds of animals ... All history is animal history, in a sense.

However, Benson acknowledges the difference between scholarship that incorporates the impact of animal life on humans but is essentially focused on humans, and that which aims 'to explore the history of nonhuman animals as subjects in their own right and for their own sakes'. ${ }^{2}$ Nearly all medical history scholarship falls into the former category. While animals do feature in it, and to an increasing degree since the turn of the twentyfirst century, ${ }^{3}$ they are usually shadowy, marginal creatures, 'mere blank

\footnotetext{
${ }^{1}$ Kirk and Worboys (2011), p. 561.

${ }^{2}$ Benson (2011) p. 5.

${ }^{3}$ Recent reviews of this literature include: Rader (2007), Kirk and Worboys (2011), Woods (2016, 2017a, 2017b), Kirk (2017).

(C) The Author(s) 2018

A. Woods et al., Animals and the Shaping of Modern Medicine,

Medicine and Biomedical Sciences in Modern History, https://doi.org/10.1007/978-3-319-64337-3_1
} 
pages onto which humans wrote meaning'. 4 They appear because of their implications for human health and medicine, or because of their capacity to illuminate wider developments in human history, such as the growth of government, colonialism and international trade.

This volume breaks new ground in applying Benson's second perspective to medical history: 'to explore the history of nonhuman animals as subjects in their own right and for their own sakes'. ${ }^{5}$ Humans remain important, of course, for ultimately we can only know about animals from the records that humans have created, and which reflect human interests in animals. However, by taking animals seriously as historical subjects, it is possible to shed a different light on human history by revealing the myriad ways in which animals have influenced human actions and perceptions. Adopting this approach also illuminates animals as creatures with their own histories, which have been profoundly altered by their relationships with humans, and the roles that humans have decided they should perform. It results in a richer, less anthropocentric account of the medical past, which reveals how, in different times and places, animals have experienced medicine, how they have been produced by it and how they have changed it.

In widening the historical lens to incorporate animals and their fashioning into medical subjects and objects, this volume pursues three key goals. First, it seeks to make a programmatic contribution to the field of medical history by elucidating some of the largely unrecognized ways in which animals have informed the knowledges, practices and social formations of medicine. Through analysing key contexts in which animals have attracted medical attention and with what effects, it will expose a series of medical problems, concerns, personnel and practices that barely feature in existing scholarship. In addition, by studying the historical positioning of animals at the shifting boundaries between medicine, veterinary medicine and the life sciences, it will cast new light on the relationships between these fields. It will thereby demonstrate how, by attending to the more-than-human dimensions of medicine, we reach new understandings of its historical identity, participants and manner of pursuit.

Second, the volume seeks to enhance the burgeoning field of animal history by offering the first substantive account of animals in medicine.

\footnotetext{
${ }^{4}$ Fudge (2006).

${ }^{5}$ Benson (2011) p. 5 .
} 
Expanding beyond much-studied laboratory contexts to explore the medical history of animals in zoos, on farms, in hospitals, post-mortem rooms and international policy arenas, it illuminates the diverse species that have participated in medicine, the many roles they have played in it, and how their bodies and habits have both shaped and been shaped by its ideas, practices and institutions. Crucially, the volume highlights how these diverse species forged multispecies networks, thereby extending animal history's typical focus on the dyadic relationships between humans and another species of animal.

The third objective of this volume is to speak to the twenty-first-century initiative known as One Health $(\mathrm{OH})$. Featuring prominently in medical, veterinary and scientific publications, and in national and international health policy and position statements, $\mathrm{OH}$ pursues an expansive vision of improving health and wellbeing through the multidisciplinary study of problems at the interface of humans, animals and their environments. For its proponents, $\mathrm{OH}$ represents a necessary response to a host of shared threats to human and animal health, such as emerging diseases that transmit between animals and humans, antimicrobial resistance, food insecurity, food safety and climate change. They argue that such issues cannot be tackled effectively within the traditional disciplinary compartments of human medicine, veterinary medicine and the life sciences. Rather, integrated, coordinated approaches are required, in which the health of animals is considered in relation to the health of humans and the environment. ${ }^{6}$ This volume situates $\mathrm{OH}$ within a longer historical context by illuminating certain precedents to this way of working. It also offers a critical, empirically grounded perspective on its operation today by exploring the circumstances that gave rise to its emergence as a self-conscious movement, and how its proponents conceptualize the roles of animals within it.

In addressing these three objectives, the volume also addresses three distinct audiences: historians of animals, historians of science and medicine, and health professionals concerned with $\mathrm{OH}$ today. The remainder of this chapter introduces the history of animals as a field of enquiry, and situates this study in relation to it. While historians of animals will be familiar with its discussion of the methodological and conceptual issues

\footnotetext{
${ }^{6}$ For example: Gibbs (2014), American Veterinary Association, Centers for Disease Control and Prevention, One Health Initiative.
} 
that are important to the writing of animal histories, we present them here for the benefit of medical historians who may not be familiar with them. We also provide an important overview of how we approach the history of animals in medicine, and conclude by elaborating on the volume's objectives, outlining its research questions and introducing the case studies that follow.

\subsection{Why Animals?}

The ways in which non-human animals have shaped human history is a pressing and important issue for historians today. Recent years have witnessed increasing engagement with the subject, manifesting in a burgeoning body of literature that draws on perspectives from material culture studies, science and technology studies, zoology, performance studies, and environmental, social and cultural history. Directing their attention to a variety of animal species, authors have addressed the lives and experiences of animals, their categorization and manipulation by humans, their relationships with humans and environments, and their representations within art and literature. ${ }^{7}$ The eclectic methods of animal history, and the many differences between its animal subjects (some of which had more historical similarities with humans than with each other) have led some historians to ask whether it can be said to constitute a coherent field of enquiry, or whether it primarily offers an approach to animals which can be applied to all existing types of history. ${ }^{8}$ Insofar as animal history is a field, this volume is intended to be a contribution to that body of work, but it also draws on animal history ideas and approaches in order to develop new perspectives on medical history.

Animal historians acknowledge that the significance of animals to war, agriculture, science, colonialism, sport and the environment means that they have long featured in scholarly histories, but usually as supporting

\footnotetext{
${ }^{7}$ Seminal works include: Ritvo (1987), Kete (1994), Anderson (2004). Valuable edited collections include: Henninger-Voss (2002), Rothfels (2002), Kalof and Resl (2007), Brantz (2010), Shaw (2013a, 2013b), Nance (2015). An even larger scholarship addresses the contemporary dimensions of human-animal relationships, drawing on disciplines such as philosophy, anthropology, geography, English literature and cultural studies. For an introductory overview, see Marvin and McHugh (2014). Key authors who have set the framework for thinking about these issues include: Agamben (2002), Derrida (2002), Wolfe (2003), Haraway (2008).
}

${ }^{8}$ Swart (2007), Andrews (n.d.). 
actors in the drama of human history. Their stated intention is to bring animals in from the margins and position them at the centre of historical analysis in order to explore the intertwining of human and animal lives, and the development of human ideas about, and relationships with, animals. ${ }^{9}$ Conceptualizing animals as creatures with their own histories and the unintentional capacity to effect historical change, authors seek to trace 'the many ways in which humans construct and are constructed by animals in the past'. ${ }^{10}$ The purpose of these analyses is not simply to fill a gap in the writing of human history but to rethink conventional historiographies. This volume follows their lead in acknowledging animals as shapers of medicine in history, and also as shapers of the ways in which we, as scholars, perceive and write about medical history. ${ }^{11}$

Developments beyond the academy have helped to precipitate this 'animal turn'. Since the later twentieth-century, animal-related causes, from opposition to factory farming and animal experimentation, to the wider improvement of animal welfare, have gained increasing public support and political traction. Portrayed variously as victims of, or contributors to, environmental degradation, animals have also become a key aspect of wider concerns about human interactions with the natural world. Meanwhile, the impacts of diseases such as bovine spongiform encephalopathy (BSE) and avian influenza, which emerged in animals and spread to people, have made the health connections between humans and animals more visible and threatening. These developments have prompted much reflection on human responsibilities for nonhuman others, and how to live sustainably with them. ${ }^{12}$ They have also encouraged animal scientists such as ethologists, vets and ecologists, to study the sentience and subjectivities of animals, and their relationships with their environments. ${ }^{13}$

Enhanced concern for animals and human-animal relations in the present has helped to draw attention to their pasts within different domains of historical scholarship. Situating animals within nature as constituents

\footnotetext{
${ }^{9}$ Ritvo (2002), Fudge (2002), Kean (2012), Sivasundaram (2015).

${ }^{10}$ Fudge (2006).

${ }^{11}$ We thank Tamar Novick of the Max Planck Institute for the History of Science, Berlin, for making this observation.

${ }^{12}$ Ritvo (2002), Shaw (2013a, 2013b), Vandersommers (2016).

${ }^{13}$ For example: Bekoff (2002), Grandin and Johnson (2005).
} 
of environments and ecosystems, environmental historians have explored the interplay between 'nature' and 'culture' in the shaping of human pasts. ${ }^{14}$ Challenging the very notion of a nature-culture dichotomy and the priority it awards to human 'culture' over animal 'nature', posthumanist scholars have sought to understand how human and animal differences, essences and linkages have been constructed through historically specific encounters. ${ }^{15}$ By contrast, for social and cultural historians, the fact that 'humans are always, and have always been, enmeshed in social relations with animals' ${ }^{16}$ calls for a social historical approach to animal histories. Their work has established animals as the latest beneficiaries of 'history from below', a genre that originated in the 1970s with E.P. Thompson's history of the working classes, and expanded subsequently to incorporate other neglected historical subjects such as women, colonized peoples, marginalized ethnic groups and the mentally ill. ${ }^{17}$ The animals studied tend to be celebrity animals, charismatic wildlife and those domesticated species that have entered into close relationships with humans. Other, more marginal creatures have been neglected. This volume offers a partial corrective by examining the medical histories of some uncharismatic and historically overlooked animals, such as tapeworms and farmed livestock.

As with the other groups targeted by 'history from below', there is an explicit political dimension to much animal history writing. Some scholars, who locate themselves within the field of critical animal studies, aim to improve animal lives in the present by uncovering and criticizing the ways in which humans have exploited them in the past. ${ }^{18}$ For other animal historians, these narratives of animal domination and oppression are too simplistic. They, too, are often keen to effect present-day changes in attitudes to animals by revealing their treatment in the past. Consequently, they remain alert to the power dynamics that have informed past human-animal relationships. ${ }^{19}$ However, they also emphasize the complexity and historical specificity of those relationships,

\footnotetext{
${ }^{14} \mathrm{McNeill}$ (2000), Nash (2005), Cronon (1990).

${ }^{15}$ Lorimer (2009), Cole (2011).

${ }^{16}$ Philo and Wilbert (2000) p. 2. See also Swart (2007) p. 276, Eitler (2014) p. 262.

${ }^{17}$ Ritvo (2002), Kean (2012). For a history of animals as workers, see Hribal (2007).

${ }^{18}$ Taylor and Twine (2014), Institute for Critical Animal Studies.

${ }^{19}$ Fudge (2012).
} 
and the 'resistance, compliance and compromise' that variously characterized them. ${ }^{20}$ This volume follows their lead in believing that historians have a moral obligation to document how human actions have impacted animal lives. It seeks to develop a nuanced understanding of the humananimal relationships that were forged through medical research and practice, and to analyse the implications of those relationships for humans, animals and medicine.

\subsection{Writing Animal Histories}

There are particular challenges associated with writing the history of animals. Some scholars have questioned whether it is even possible. Pearson and Weismantel state that the challenges are at once ontological ('a question of imagining animal being'), epistemological (because our communications with animals are non-verbal) and methodological (how can we write authentic animal histories when the only records that survive of them were created by humans?). They suggest that these difficulties are linked: if animals have no voices, they cannot leave records from which historians can write their pasts; without language, consciousness or intentionality they are unable to participate in history except as subjects of biological evolution. For some commentators, it follows that the study of animals belongs within the natural sciences not the humanities-which are by definition concerned with human society and culture. ${ }^{21}$ This stance has roots in Christian theology, which asserts human dominion over animals, and in Enlightenment thinking, which posits fundamental distinctions between humans and animals, nature and culture. ${ }^{22}$

These dichotomies and the exceptional status they award to humans have been challenged by post-modern and post-humanist scholarship, and by studies of developments within technoscience, food production and climate science, which provide concrete examples of the impossibility of separating nature from society. ${ }^{23}$ Historical analyses lend support to these challenges. By illuminating circumstances in which particular

\footnotetext{
${ }^{20}$ Pooley-Ebert (2015) p. 165.

${ }^{21}$ Pearson and Weismantel (2010).

${ }^{22}$ Thomas (1983).

${ }^{23}$ Latour (1993), Mitchell (2002), Schrepfer and Scranton (2003), Agamben (2002), Lorimer (2009).
} 
humans (notably women, the mentally ill and certain ethnic groups) were invested with animal characteristics, and certain animals (notably horses, dogs and primates) were awarded privileged, quasi-human status, it reveals that human-animal boundaries are not fixed in nature but shaped by human society and culture. Therefore animals and animality are not distinct from, but constitutive of the human, in ways that change over time and place. $^{24}$

If the human-animal boundary is blurred, then where does this leave assertions that without cognition or conscious thought, animals cannot be active historical subjects? Scholars have tackled this question by considering whether the ability to act on history can exist separately from the intention to do so, and whether animals can be historical subjects without necessarily possessing subjectivity. They suggest that while animals do not understand or care about human knowledge, politics and cultures, nevertheless they can make a difference to them. Therefore, in principle, animals do possess agency-where agency constitutes the ability to act. ${ }^{25}$ For animal historians, the nature of that agency is an empirical question. It is not a natural, permanent attribute; rather, it emerges and is performed through social relationships, which vary by time, space and species. ${ }^{26}$

In locating animal agency within human-non-human encounters, many scholars draw on ideas associated with Actor Network Theory (ANT). Developed within the field of science studies by Bruno Latour, Michel Callon and John Law in the 1980s, ANT sought to remove distinctions between nature and society. It represented a critical response to prevailing understandings of scientific knowledge and technical innovation as either realist or sociological. ${ }^{27}$ It has since been adopted and developed by scholars in many other disciplines. ANT has many variants but it essentially proposes a relational way of understanding the world. In widening the traditional analytical lens to incorporate interacting human and non-human entities, it opens up a space for animals as historical actors. ANT presents agency, and actors, as products of the unstable web

\footnotetext{
${ }^{24}$ Ritvo (1995), Fudge (2002), Ritvo (2007), Hochadel (2010), Bourke (2011), Davis (2014).

${ }^{25}$ Fudge (2006), Law and Mol (2008), McFarland and Hediger (2009).

${ }^{26}$ Philo and Wilbert (2000), Eitler (2014), Pooley-Ebert (2015).

${ }^{27}$ Callon and Law (1986), Latour $(1988,2005)$.
} 
of relations (or networks) in which all are embedded. The configuration of these networks affects how the capacity to act is distributed among and deployed by its members. Their actions reshape ideas and practices, bodies and materials, experiences and social relations, and, by extension, the network itself. In this formulation, it is not only the animal's capacity to effect historical change but also the animal itself which is constantly being reconfigured through its embeddedness in multiple interactive, ever-changing relationships. ${ }^{28}$

Animal studies scholars frequently cite ANT when reflecting on the agency of animals. However, their recognition that pre-existing power differentials, social contexts and species differences have an important bearing on network formation, the relationships of its participants, and consequently on the animal's ability to act, seems to support criticisms of ANT's 'flat ontology'-its refusal to acknowledge any differences between actors other than those created through networks. ${ }^{29}$ While we agree with such criticisms, we, too, find ANT to be a useful heuristic device because of the significance it awards to relationships. It suggests that through scrutinizing 'the entire lived experience of quotidian and extraordinary interactions - embodied and imaginary, material and symbolic-that occur within space and in particular locations, and involve humans and animals in multiple forms of engagement and exchange', ${ }^{30}$ we can work out how animals have changed medicine and have, in turn, been changed by it. ${ }^{31}$ Moreover, by privileging relationships, as ANT exhorts us to, we are able to identify the interconnections between multiple species. ${ }^{32}$

Thinking about animals in history has also been profoundly influenced by Donna Haraway's writing. While acknowledging the uneven distribution of pain and suffering between human and animals, she perceives their relationships to be characterized by mutual adaptation rather than exploitation, and seeks to determine how, in historically and culturally specific circumstances, humans and animals come together in 'materialsemiotic nodes or knots in which diverse bodies and meanings coshape

\footnotetext{
${ }^{28}$ Pearson (2013) pp. 128-45, Eitler (2014).

${ }^{29}$ Barron (2003), McLean and Hassard (2004).

${ }^{30}$ Pearson and Weismantel (2010).

${ }^{31}$ Kean (2012).

${ }^{32}$ Pettit et al. (2015).
} 
one another'. ${ }^{33}$ As Law and Mol point out, this does not mean that animals have the capacity to control history, just that by entering into relationships with human and other non-human actors they are able to make a difference to it. Their analysis of Cumbrian sheep during the British 2001 foot-and-mouth disease epidemic offers some concrete examples. The variable bodily responses of sheep to encounters with the foot-andmouth disease virus affected whether the vets that inspected them were able to detect and respond to it. The hill sheep's ability to know its place or 'heft' on the hills fashioned the landscape in ways that were valued by humans, and which led ultimately to their exemption from the government's contiguous culling policy. These outcomes were not necessarily predictable: they resulted from the unstable, indeterminate webs of practices that drew together and were created by sheep and their co-actors. Law and Mol conclude that the important question is not whether but how animals act. ${ }^{34}$

We will address this question by analysing the roles that animals have performed within medical research and practice. Some of these roles will be familiar to medical historians. In laboratories, animals were fashioned into experimental subjects and manipulated to cast light on health and disease. Animals that fell sick performed roles as disease victims, and were sometimes transformed into patients. Alternatively, or additionally, they were regarded as hosts and potential transmitters of infection. Animals have also performed other, less well-documented roles in medicine: as pathological specimens, points of comparison with other species, commercial products, shapers and victims of food systems and natural environments, and vehicles for personal and professional advancement. They have often performed several roles simultaneously or sequentially throughout their lives and afterlives. Roles have reshaped animals, physically and conceptually, and therefore impacted on their histories. Roles also had their own histories that were influenced partly by human-animal relationships and their disruption by disease, and also by prevailing ideas of disease and the tools available to conceptualize, investigate and manage it. While it was humans who awarded roles to animals, animals were not passive recipients. Their bodies, behaviours and relationships with humans have invited the awarding of particular roles

\footnotetext{
${ }^{33}$ Haraway (2008) p. 4.

${ }^{34}$ Law and Mol (2008) p. 74.
} 
and influenced their performance within them. Different roles have provided animals with different opportunities to shape medicine, with ramifications for the health of both humans and animals. The concept of the animal role therefore offers a useful tool for illuminating the historical co-constitution of humans, animals and medicine.

\subsection{Animals in Medical History}

Inspired by Haraway's thinking, in 2011, Kirk and Worboys called for the history of medicine to be rewritten as a history of interspecies interactions. ${ }^{35}$ However, to date, few scholars have adopted this approach. There are only a handful of key works that foreground the relationships between humans and animals, and these focus narrowly on experimental settings. ${ }^{36}$ Studies of the co-constitution of animals and medicine are also few in number and derive more from the history of the life sciences than medical history. ${ }^{37}$ For the most part, animals fade into the background of medical history writing. ${ }^{38}$ Scholars influenced by the 'animal turn' have not been drawn to study the history of medicine, while historians of medicine have remained largely unaware of the 'animal turn'.

This situation has not arisen because animals were unimportant to medicine. On the contrary, as this volume and its extended bibliography demonstrate, they have been integral to its history. Medical scientists employed animals to develop new knowledge of bodies, minds and diseases; to generate biological products, and to test the safety and efficacy of drugs. Animals supplied nutrition to humans and transmitted diseases to them. The state of animal health powerfully influenced-and was influenced by-their environments. Animals were treated as patients, fashioned into pathological specimens, and their diseases compared across species. So far, however, these animal roles have been studied from a largely human perspective. Their capacity to shape medicine has attracted little attention, and they have been rarely studied as medical subjects 'in their own right and for their own sakes'—not even within the field of

\footnotetext{
${ }^{35}$ Kirk and Worboys (2011).

${ }^{36}$ Rupke (1990), Todes (1997), Dror (1999), Guerrini (2003), Schlich and Schlünder (2009), Kirk (2014).

${ }^{37}$ Clarke and Fujimura (1992), Clause (1993), Kohler (1994), Rader (2007).

${ }^{38}$ Woods (2017b).
} 
veterinary history, which is ostensibly focused on the health of animals as a problem in its own right. ${ }^{39}$

We can offer only tentative explanations for why animal histories of medicine have yet to be written. It may be because of the dominance of cultural studies' perspectives within animal and human-animal history, which have tended to foreground animals' cultural and symbolic roles in society rather than delving into the content and material practices of animal science and medicine. It may also result from a preference for writing the histories of individual animals that are visible in today's society and with which humans develop empathetic bonds: pet animals, zoo animals and charismatic wildlife species. Farm animals, which have wielded considerable influence over human health, are comparatively neglected. Such explanations do not apply to historians of medicine. The field's longlasting engagement with ANT, ${ }^{40}$ its preoccupation with the histories of bodies and material practices, the scientific training of many of its scholars, and their expertise-generated through writing patient histories-in thinking about medical history 'from below', means that the tools for writing animal-centred histories of medicine are already in circulation. ${ }^{41}$ The failure to apply them may be due to the anthropocentrism that characterized most fields of history writing until relatively recently. However, we believe that disciplinary traditions may also be to blame.

It is now more than 20 years since the late Roy Porter asserted that, 'in the academic world, it is automatically assumed that a "historian of medicine" is a person who works on the history of human medicine' ${ }^{42}$ $\mathrm{He}$ attributed this assumption to modernist notions of human difference from, and primacy over, animals. While in the intervening years these notions have come increasingly under attack, scholars have not significantly revised their perceptions of what constitutes medical history. There remains an implicit assumption that human health and medicine lie at the heart of this field. Sick animals whose health had no direct consequence for humans are relegated to the small subfield of veterinary

\footnotetext{
${ }^{39}$ Benson (2011) p. 5 . Susan Jones is one of the few veterinary historians to foreground animals and their relationships with humans. A good example is Jones (1997). See also Degeling (2009).

${ }^{40}$ Latour (1988).

${ }^{41}$ Porter (1985), Beier (1987), Warner (1999), Gillis (2006), Cooter (2010), Crozier (2010), Hurren (2012).

${ }^{42}$ Porter (1993) p. 19.
} 
history, while other aspects of animal life are studied by historians of biology. We hold that this compartmentalization is artificial and unhelpful. It does not reflect the historical positioning of animals within these fields, and it produces a narrowly anthropocentric framing of 'medicine' which is frequently at odds with its historical identity.

This volume challenges such conceptions by revealing that modern medicine, as developed in the West over the last two centuries, was a more-than-human endeavour, whose boundaries with veterinary medicine and biology were porous and in a constant state of flux. In certain historical contexts, animals contributed to the compartmentalization of these domains. In others, they helped to break down the barriers between them, particularly through their investigation within boundary-crossing fields such as parasitology, zoology, comparative medicine, nutrition and agriculture. ${ }^{43}$ Animals contributed to the formation of these fields, and were, in turn, formed by them. By elucidating these processes, this volume not only sheds light on the history of animals. In identifying the ideas, methods, problems, places and people who engaged with their health, it also develops a new perspective on medicine itself-and therefore on what constitutes the field of medical history.

In developing this animal-centred medical history, we have had to engage with the tricky issue of how to write the histories of non-verbal creatures when the only records that survive of them were created by humans. Some scholars have attempted to overcome this problem by using modern scientific understandings of animals to retrospectively interpret their behaviours and experiences. ${ }^{44}$ As historians of science and medicine, we find this approach deeply problematic, because in granting a timeless universality to scientific interpretations that are in fact products of specific historical circumstances, it reifies the natureculture divide. ${ }^{45}$ Other scholars have argued that the problem cannot be overcome; that it is impossible to truly 'know' the authentic historical animal because surviving records are mere cultural representations of them. ${ }^{46}$ Swart has challenged this view. Questioning the very notion of authenticity, she points out that the 'facts' about animals are always

\footnotetext{
${ }^{43}$ Woods $(2017 \mathrm{c})$.

${ }^{44}$ For example: Pearson (2013), Foote and Gunnels (2015), Pooley-Ebert (2015).

${ }^{45}$ Latour (1993).

${ }^{46}$ Fudge (2002) p. 6.
} 
human interpretations, not 'real' accounts of them. ${ }^{47}$ Benson goes further by arguing that because animals have informed the human production of records of them, such records - or traces - are more than cultural representations; they comprise 'material-semiotic remnants' of animals, a nexus of language and materiality that offer 'unintentional indexes of a now-absent presence'. ${ }^{48}$

Inspired by Benson's thinking around animal traces, we approach medical historical records of animals as evidence of their interactions with humans, whose analysis reveals how animals made a difference to, and were changed by, medicine. We perceive multiple layers of animal traces which gained meaning in reference to each other. There are the immediate material remains of diseased animal bodies such as taxidermy and museum specimens. Then there are the narratives, statistics and images that humans have created from these materials and from other long-dead animals whose remains were not preserved. Finally, there are the knowledge-practices and social relationships that were fashioned by and from these creations. In studying these traces, we ask not only what they reveal about the health of animals in history and the roles that animals played in medicine. By reflecting on why this 'animal archive' was created in the first place, we also learn about the animal's capacity to attract human attention, and the relationships that bound them. ${ }^{49}$

\subsection{One Health and its Histories}

One of the inspirations and intended audiences for this work is the contemporary movement for $\mathrm{OH}$, whose features and early twenty-first-century emergence are explored in Chapter $6 . \mathrm{OH}$ is underpinned by the belief that some of the most important health threats faced today are not species specific, and consequently can only be tackled by interdisciplinary working across the domains of human medicine, veterinary medicine and the life sciences. Its integrated approach to human and animal health implies that medicine cannot achieve its goals through a purely anthropocentric approach. Just as other contemporary agendas have prompted historians to study animal pasts, so has the push for $\mathrm{OH}$ drawn our attention to the roles played by animals in the history of medicine.

\footnotetext{
${ }^{47}$ Swart (2015).

${ }^{48}$ Benson (2011) p. 3.

${ }^{49}$ Tortorici (2015).
} 
While the term $\mathrm{OH}$ is new, the concept is not. This is well recognized by $\mathrm{OH}$ advocates, who use historical observations of human-animal health connections in attempts to legitimize their agenda, and win momentum and funding for it. ${ }^{50}$ They locate the roots of $\mathrm{OH}$ in an earlier agenda known as One Medicine (OM), which developed in the 1960s and 1970s with the aim of bringing human and veterinary medicine into closer alignment. ${ }^{51} \mathrm{OM}$ was, in turn, presaged by work dating back to the nineteenth century in the fields of comparative medicine and veterinary public health, where human and animal health problems were considered in tandem. ${ }^{52} \mathrm{OH}$ advocates offer a single, highly selective interpretation of this history. They highlight the work of key high-profile figures whose work crossed the human-animal divide and had a lasting impact on medicine: Louis Pasteur, Robert Koch, William Osler, Theobald Smith, John McFadyean and Rudolph Virchow (who is frequently quoted, in the absence of any identifiable source material, as stating that 'between human and animal medicine there is no dividing line').$^{53}$ Extracting these individuals from their historical contexts, $\mathrm{OH}$ advocates present them as far-sighted geniuses who recognized the merits of a $\mathrm{OH}$ approach. There is little understanding of what, within the context of the time, these men thought they were doing and why; whether their work was typical or unusual; and how animals might have shaped, or been shaped, by it.

One of the goals of this volume is to develop a more critical, evidencebased, animal-centred history of $\mathrm{OH}$ by documenting and explaining the circumstances in which animals and their diseases became important to human medical agendas. By identifying what motivated their investigation by a range of lesser-known individuals, how these investigations were pursued in policy and practice, and with what implications for human and animal health, the book will illuminate precedents to $\mathrm{OH}$ today, and draw insights of relevance to its future operation. It will also offer an explanation for the emergence of $\mathrm{OH}$ as a self-conscious twentyfirst-century agenda and unpack the place of animals within it.

\footnotetext{
${ }^{50}$ Woods and Bresalier (2014).

${ }^{51}$ Schwabe (1984), Zinsstag et al. (2011).

${ }^{52}$ Bresalier et al. (2015).

${ }^{53}$ Schwabe (1984), Michell (2000) pp. 101-6, Day (2008) pp. 151-3.
} 
We do not attempt a complete account of the history of animals in medicine: the subject is too vast and too neglected. ${ }^{54}$ Instead, we aim to set a new research agenda and to illustrate where it might lead through a series of case studies that are drawn from the authors' individual research programmes. These studies explore animal histories of medicine, and histories of animals in medicine, on scales ranging from the local to the global, from the 1830s to the present day. They are designed to be read separately as standalone examples of the contexts in which animals became important to medicine and the difference they made to it. Read collectively, they illuminate the diverse species, spaces, methods, people, problems and contexts of enquiry that were involved in constructing animal health as a medical problem. In tracing how that construction changed over time, they also trace the shifting place of animals within medicine, and how animals moulded its relationships with veterinary medicine and the life sciences.

Cross-cutting questions include: What circumstances attracted human attention to animals and their diseases, and what networks developed around them? How can we account for the attention paid to animals by members of the medical profession, which is generally assumed to be exclusively concerned with the health of humans? How and where were investigations and interventions performed on animals, and what roles did animals play within them? While our human protagonists' affective relationships with animals are generally impossible to discern, the concept of the animal role permits analysis of the multiple values that humans assigned to animals. We also ask: What difference did animals make to medicine - to its ideas, practices, the health of its human and animal subjects, and its interpersonal and interdisciplinary relationships? What difference did medicine make to animals - to their bodies and experiences in life, the manner and timing of their deaths, and to their afterlives?

In selecting which aspects of the history of animals in medicine to study, we made a deliberate decision not to focus on the laboratorybased subjects of experimental medicine. This is partly because these animals, notably rodents and dogs, already feature in the handful of existing animal-centred accounts of medical history. It is also because

\footnotetext{
${ }^{54}$ For a chronological overview, see Bresalier et al. (2015).
} 
experimental medicine is already overrepresented within medical history scholarship. The widely held perception that the pursuit of knowledge through experiments is one of the defining features of modern medicine, means that scholars have dedicated considerable attention to its history, starting with the growth of experimental physiology around 1800, and progressing to the emergence of other experimental sciences: bacteriology in the 1860s and 1870s, pharmacology, endocrinology, nutrition science and immunology in the decades around 1900, and biomedicine in the post-Second World War era. ${ }^{55}$ The attention lavished on the topic is such that many scholars seem to assume by default that the history of animals in medicine is a history of experimental animals, or 'animal models' of disease, that were manipulated in laboratories for the benefit of human health.

This volume seeks to dislodge that perception through a series of case studies that decentre not only humans but also laboratory-based experimentation from the history of modern medicine. The studies address a series of other important medical contexts whose histories have been obscured by the historiographical focus on the laboratory: natural history, zoology, parasitology, comparative anatomy, ecology, nutrition and agriculture. Lying at the borderlands of human medicine, veterinary medicine and the life sciences, and shedding light on their shifting points of intersection, analysis of these contexts shifts the historical focus away from laboratory rodents and dogs towards a wide array of other species that hardly ever feature in accounts of medical history: zoo animals, Scottish sheep, cows of the developing world, and the tapeworm, Echinococcus granulosus. These animals performed various roles, including, but not confined to, those of disease victims, patients, experimental material, shapers and products of their environments, hosts and transmitters of infection, tools for thinking comparatively across species, spontaneous (as opposed to experimentally designed) models of disease, and sources of human nutrition. Their investigation relied not only on experimental practices but also on observation, categorization, comparison, statistical analysis and clinical trials. These methods were applied far beyond the laboratory, in animal houses, post-mortem rooms, hospitals, farms, field stations and slaughterhouses. By drawing our attention to these historically neglected aspects of medicine, the animals studied in this volume also expand and

\footnotetext{
${ }^{55}$ Guerrini (2003), Lowy (2003), Rader (2007), Schlich et al. (2009), Löwy (2011), Franco (2013).
} 
alter received conceptions of what constituted medicine in history, and who were its key actors.

The first case study, presented in Chapter 2, is situated in Britain's mid-nineteenth-century zoological gardens, particularly those located in London and Dublin. It documents the diseases and deaths that beset their diverse animal inhabitants, and argues that as a consequence, the zoos became important sites of medical research and practice. It shows how medical men who helped to run the zoos, and medical visitors who hoped to make their names within them, used their knowledge and practice of human medicine and comparative anatomy to advance the health of zoo animals, and devise comparative pathological understandings of their diseases. These men awarded animals the roles of patients, victims of their environments, pathological specimens and points of interspecies comparison. They manipulated animal bodies, surroundings and management in ways that were shaped by animal biologies and behaviours. Through these activities, the zoo became medical, and medicine zoological. An array of vertebrate species fell under the medical gaze, and helped to generate new knowledge of health and disease that found applications in human medicine.

In Chapter 3 the focus shifts to diseased and dying sheep on farms in and around Scotland at the turn of the twentieth century. It reveals how these animals came to be regarded as victims of their environment, and positioned at the hub of a research network containing farmers, doctors, vets, natural historians and zoologists. It examines the investigations performed by this network, and how sheep fashioned and were fashioned by them. It then describes and explains key changes to the network, which shifted the location of investigations from farms to laboratories, and distanced doctors and practical farmers from the scientific study of sheep. Awarded new roles as hosts and transmitters of infection, sheep lost influence over investigators' activities. Meanwhile, veterinarians sought to capture sick sheep for themselves by claiming superior knowledge that derived from their unique relationships with them. In these ways, sheep first integrated, and then contributed to widening divisions between the various experts in their diseases.

Chapter 4 is concerned with diseased and undernourished dairy cattle, and how they came to be perceived not simply as threats to farming profits but as contributors to world hunger and ill health. Moving 
from interwar Britain and its empire, to the post-war international stage, it explores how developments in nutritional science and veterinary medicine, combined with economic depression, food shortages and the effects of war, drew attention to the undernourished, unhealthy bodies of both humans and cows, and suggested connections between them. By the early 1950s, under the United Nations and its agencies, cows had become key participants in the campaign against human hunger in the developing world. Their unproductive bodies inspired the formation of new health structures that brought together experts in human health, nutrition, veterinary medicine and agricultural science to create new types of cow that would prove more capable of supporting human health and nutrition.

Chapter 5 continues to cross borders between nations and disciplines in its study of the tapeworm, Echinococcus granulosus, and the ideas and investigations it inspired. It is particularly concerned with the work of parasitologist Calvin Schwabe, who is better known as a progenitor of the recent movement for $\mathrm{OH}$. For Schwabe, Echinococcus was an animal in its own right, an active, opportunistic participant in both human and non-human ecological and cultural interactions. In following Schwabe as he followed Echinococcus, from the laboratory into human communities and multispecies ecosystems, and from Beirut to Kenya to California, this chapter reveals that the roots of his commitment to unifying human and veterinary medicine lay in his deep-seated engagement with the parasite. His investigations into its body and behaviour led him to view distinctions between human and non-human species as culturally contingent rather than fundamentally biological. This fed his conviction that human and veterinary medicine could only function truly effectively when practised in tandem.

Chapter 6 takes forward the story of $\mathrm{OH}$ by exploring its emergence as a self-conscious movement, dedicated to the integrated study of problems at the interface between human health, animal health and the environment. It explores how Schwabe's work influenced, and was reconfigured by, this movement, and locates its early development in several research and policy networks, which produced not one but several different forms of $\mathrm{OH}$. The chapter also examines how humananimal health relationships have inspired and shaped $\mathrm{OH}$, and how they are represented-in sometimes contradictory ways-in the texts and images produced by its researchers and advocates. It argues that in privileging the roles of animals as transmitters of diseases to humans, and 
experimental models of human diseases, $\mathrm{OH}$ rebrands longstanding research agendas that are far more concerned with the health of humans than that of animals.

Chapter 7 concludes by summarizing what these chapters have revealed about the medical history of animals and the animal history of medicine. It reflects on the implications of these findings for how historians think about and study the history of medicine, and for how $\mathrm{OH}$ advocates conceptualize and pursue their integrating agenda. The volume ends with an annotated bibliography of animals in the history of medicine, which offers an entry point for scholars who are new to the field and is organized around some of the key animal roles that are explored in the chapters.

\section{BIBLIOGRAPHY}

Agamben, Giorgio. The Open: Man and Animal. Stanford: Stanford University Press, 2002.

American Veterinary Association. "One Health - It's All Connected." Accessed February 19, 2017. https://www.avma.org/onehealth.

Anderson, V. Creatures of Empire: How Domestic Animals Transformed Early America. Oxford: Oxford University Press, 2004.

Andrews, Thomas. "Review of Nance, S. (ed.) The Historical Animal." Accessed February 19, 2017. https://networks.h-net.org/node/19397/ reviews/148458/andrews-nance-historical-animal.

Barron, Colin. "A Strong Distinction between Humans and Non-Humans is No Longer Required for Research Purposes: A Debate between Bruno Latour and Steve Fuller." History of the Human Sciences 16 (2003): 77-99.

Beier, L.M. Sufferers and Healers: The Experience of Illness in Seventeenth Century England. London: Routledge, 1987.

Bekoff, M. Minding Animals: Awareness, Emotion and Heart. Oxford: Oxford University Press, 2002.

Benson, E. "Animal Writes: Historiography, Disciplinarity, and the Animal Trace." In Making Animal Meaning, edited by L. Kalof and G.M. Montgomery, 3-16. East Lansing: Michigan State University Press, 2011.

Bourke, Joanna. What it Means to be Human: Reflections from 1791 to the Present. London: Virago, 2011.

Brantz, D. (ed.) Beastly Natures: Animals, Humans and the Study of History. London: University of Virginia Press, 2010.

Bresalier, M., A. Cassidy and A. Woods. "One Health in History." In One Health: The Theory and Practice of Integrated Health Approaches, edited by J. Zinsstag, E. Schelling, D. Waltner-Toews, M. Whittaker and M. Tanner, 1-15. Wallingford: CABI, 2015. 
Callon, Michel and John Law. "Some Elements of a Sociology of Translation: Domestication of the Scallops and the Fishermen of St Brieuc Bay." In Power, Action and Belief: A New Sociology of Knowledge, edited by John Law, 196223. London: Routledge, 1986.

Cassidy, Angela, Rachel Mason Dentinger, Kathryn Schoefert and Abigail Woods. 'Animal Roles and Traces in the History of Medicine.' In Animal Agents: The Non-Human in the History of Science, edited by Amanda Rees. BJHS Themes 2 (2017): 11-33.

Centres for Disease Control and Prevention. "One Health." Accessed February 19, 2017. https://www.cdc.gov/onehealth.

Clarke, Adele and Joan Fujimura (eds.). The Right Tools for the Job: At Work in Twentieth-Century Life Sciences. Princeton: Princeton University Press, 1992.

Clause, Bonnie. "The Wistar Rat as a Right Choice: Establishing Mammalian Standards and the Ideal of a Standardized Mammal." Journal of the History of Biology 26 (1993): 329-49.

Cole, Lucinda. "Introduction: Human-Animal Studies and the Eighteenth Century." The Eighteenth Century 52 (2011): 1-10.

Cooter, Roger. "The Turn of the Body: History and the Politics of the Corporeal." Arbor Ciencia, Pensamiento y Cultura 186 (2010): 393-405.

Cronon, William. "Modes of Prophecy and Production: Placing Nature in History," Journal of American History 76 (1990): 1122-31.

Crozier, Ivan. "Bodies in History - The Task of the Historian." In The Cultural History of the Human Body, vol. 6 1920-present, edited by I. Crozier, 1-20. London: Bloomsbury, 2010.

Davis, David Brion. The Problem of Slavery in the Age of Emancipation. New York: Knopf, 2014.

Day, Michael. "One Health and the Legacy of John McFadyean." Journal of Comparative Pathology 139 (2008): 151-3.

Degeling, Chris. "Picturing the Pain of Animal Others: Rationalising Form, Function and Suffering in Veterinary Orthopaedics." History and Philosophy of the Life Sciences 31 (2009): 377-403.

Derrida, J. "The Animal That Therefore I Am (More to Follow)." Critical Inquiry 28 (2002): 369-418.

Dror, O.E. "The Affect of Experiment. The Turn to Emotions in AngloAmerican Physiology, 1900-1940." Isis 90 (1999): 205-37.

Eitler, Pascal. "Animal History as Body History: Four Suggestions from a Genealogical Perspective.” Body Politics 2 (2014): 259-74.

Foote, N. and C. Gunnels. "Exploring Early Human-Animal Encounters in the Galapagos Islands Using a Historical Zoology Approach.” In The Historical Animal, edited by Susan Nance, 203-20. New York: Syracuse University Press, 2015. 
Franco, Nuno Henrique. "Animal Experiments in Biomedical Research: A Historical Perspective." Animals 3 (2013): 238-73.

Fudge, Erica. Perceiving Animals: Humans and Beasts in Early Modern English Culture. Urbana: University of Illinois Press, 2002.

Fudge, Erica. "A Left-Handed Blow: Writing the History of Animals." In Representing Animals, edited by N. Rothfels, 3-18. Bloomington: Indiana University Press, 2002.

Fudge, Erica. "Ruminations 1: The History of Animals." (2006). Accessed February 19, 2017. https://networks.h-net.org/node/16560/pages/32226/ history-animals-erica-fudge.

Fudge, Erica. "Renaissance Animal Things." In Gorgeous Beasts: Animal Bodies in Historical Perspective, edited by J. Landes, P.Y. Lee and P. Youngquist, 41-56. Pennsylvania: Penn State University Press, 2012.

Gibbs, E.P.J. "The Evolution of One Health: A Decade of Progress and Challenges for the Future." Veterinary Record 174 (2014): 85-91.

Gillis, J. "The History of the Patient History since 1850." Bulletin of the History of Medicine 80 (2006): 490-512.

Grandin, T. and C. Johnson. Animals in Translation. London: Bloomsbury, 2005.

Guerrini, Anita. Experimenting with Humans and Animals: From Galen to Animal Rights. London: John Hopkins University Press, 2003.

Haraway, Donna. When Species Meet. Minneapolis: University of Minnesota Press, 2008.

Henninger-Voss, M. (ed.). Animals in Human Histories: The Mirror of Nature and Culture. Rochester: University of Rochester Press, 2002.

Hochadel, Oliver. "Acculturating Wild Creatures." In Beastly Natures: Animals, Humans and the Study of History, edited by D. Brantz, 81-107. London: University of Virginia Press, 2010.

Hribal, J. "Animals, Agency and Class: Writing the History of Animals from Below." Human Ecology Forum 14 (2007): 101-12.

Hurren, E. "'Abnormalities and Deformities': The Dissection and Interment of the Insane Poor, 1832-1929." History of Psychiatry 23 (2012): 65-77.

Institute for Critical Animal Studies. "About." Accessed 19 February 2017. http://www.criticalanimalstudies.org/about/.

Jones, Susan. "Framing Animal Disease: Housecats with Feline Urological Syndrome, their Owners, and their Doctors." Journal of the History of Medicine and Allied Sciences 52 (1997): 202-35.

Kalof, L. and B. Resl (eds.). A Cultural History of Animals. Oxford: Berg, 2007.

Kean, Hilda. "Challenges for Historians Writing Animal-Human History: What Is Really Enough?" Anthrozoos 25 (2012): 57-72.

Kete, K. The Beast in the Boudoir: Pet-keeping in Nineteenth Century Paris. London: University of California Press, 1994. 
Kirk, R.G.W. and M. Worboys. "Medicine and Species: One Medicine, One History?" In The Oxford Handbook of the History of Medicine, edited by Mark Jackson, 561-77. Oxford: Oxford University Press, 2011.

Kirk, R.G.W. "The Invention of the 'Stressed Animal' and the Development of a Science of Animal Welfare, 1947-86." In Stress, Shock, and Adaptation in the Twentieth Century, edited by D. Cantor and E. Ramsden, 241-62. Rochester: University of Rochester Press, 2014.

Kirk, R.G.W. "Animals in Science. Laboratory Life from the Experimental Animal to the Model Organism." In Routledge Companion to AnimalHuman History, edited by Hilda Kean and Phillip Howell. London: Routledge, 2017.

Kohler, R. Lords of the Fly. Chicago: University of Chicago Press, 1994.

Latour, Bruno. The Pasteurization of France. Translated by Alan Sheridan and John Law. London: Harvard University Press, 1988.

Latour, Bruno. We Have Never Been Modern. Translated by Catherine Porter. London: Harvester Wheatsheaf, 1993.

Latour, Bruno. Reassembling the Social: An Introduction to Actor-NetworkTheory. Oxford: Oxford University Press, 2005.

Law, John and Annemarie Mol. "The Actor-Enacted: Cumbrian Sheep in 2001." In Material Agency Towards a Non-Anthropocentric Approach, edited by Carl Knappett and Lambros Malafouris, 57-77. London: Springer, 2008.

Lorimer, J. "Posthumanism/Posthumanistic Geographies." In International Encyclopedia of Human Geography, edited by R. Kitchin and N. Thrift, 34454. Elsevier Science, 2009.

Löwy, Ilana. "The Experimental Body." In Companion Encyclopedia of Medicine in the Twentieth Century, edited by Roger Cooter and John Pickstone, 43549. London: Routledge, 2003.

Löwy, Ilana. "Historiography of Biomedicine: 'Bio,' 'Medicine,' and In Between." Isis 102 (2011): 116-22.

Marvin, G. and S. McHugh (eds.) Routledge Handbook of Human-Animal Studies. London: Routledge, 2014.

McFarland, S. and R. Hediger. Animals and Agency: An Interdisciplinary Exploration. Leiden: Brill, 2009.

McLean, Chris and John Hassard. "Symmetrical Absence/Symmetrical Absurdity: Critical Notes on the Production of Actor-Network Accounts." Journal of Management Studies 41 (2004): 493-519.

McNeill, John. Something New under the Sun: An Environmental History of the Twentieth-Century World. London: Allen Lane, 2000.

Michell, A. "Only One Medicine: The Future of Comparative Medicine and Clinical Research." Research in Veterinary Science 69 (2000): 101-6.

Mitchell, Timothy. Rule of Experts: Egypt, Technopolitics, Modernity. London: University of California Press, 2002. 
Nance, Susan (ed.). The Historical Animal. New York: Syracuse University Press, 2015.

Nash, Linda. “The Nature of Agency or the Agency of Nature." Environmental History 10 (2005): 67-9.

One Health Initiative. "One Health Initiative Will Unite Human and Veterinary Medicine." Accessed February 19, 2017. http://www.onehealthinitiative. com/.

Pearson, Chris. "Dogs, History, and Agency." History and Theory 52 (2013): 128-45.

Pearson, S.J. and M. Weismantel. "Does 'The Animal' Exist? Toward a Theory of Social Life with Animals." In Beastly Natures: Animals, Humans and the Study of History, edited by D. Brantz, 17-39. London: University of Virginia Press, 2010.

Pettit, Michael, Darya Serykh and Christopher D. Green. "Multispecies Networks: Visualizing the Psychological Research of the Committee for Research in Problems of Sex." Isis 106 (2015): 121-49.

Philo, Chris and Chris Wilbert. "Animal Spaces, Beastly Places: An Introduction." In Animal Spaces, Beastly Places: New Geographies of HumanAnimal Relations, edited by Chris Philo and Chris Wilbert, 1-34. London: Routledge, 2000.

Pooley-Ebert, Andria. "Species Agency: A Comparative Study of Human-Horse Relationships in Chicago and Rural Illinois." In The Historical Animal, edited by Susan Nance, 148-65. New York: Syracuse University Press, 2015.

Porter, Roy. “The Patient's View: Doing Medical History from Below." Theory and Society 14 (1985): 175-85.

Porter, Roy. "Man, Animals and Medicine at the Time of the Founding of the Royal Veterinary College." In History of the Healing Professions, volume 3, edited by A. R. Mitchell, 19-30. Wallingford: CABI, 1993.

Rader, K. "Scientific Animals: The Laboratory and its Human-Animal Relations, from Dba to Dolly." In A Cultural History of Animals, Vol. 6. The Modern Age (19202000), edited by L. Kalof and B. Resl, 119-37. London: Bloomsbury, 2007.

Ritvo, Harriet. The Animal Estate: The English and Other Creatures in the Victorian Age. London: Harvard University Press, 1987.

Ritvo, Harriet. "Border Trouble: Shifting the Line between People and Other Animals." Social Research 62 (1995): 481-500.

Ritvo, Harriet. "History and Animal Studies." Society and Animals 10 (2002): 403-6.

Ritvo, Harriet. “On the Animal Turn.” Daedalus 136 (2007): 118-22.

Rothfels, N. (ed.). Representing Animals. Bloomington: Indiana University Press, 2002.

Rupke, Nicolaas (ed.). Vivisection in Historical Perspective. London: Croon Helm, 1990. 
Schlich, Thomas and Martina Schlünder. "The Emergence of 'Implant-Pets' and 'Bone-Sheep:' Animals as New Biomedical Objects in Orthopedic Surgery (1960s-2010)." History and Philosophy of the Life Sciences 31 (2009): 433-66.

Schlich, Thomas, Eric Mykhalovskiy and Melanie Rock. "Animals in SurgerySurgery in Animals: Nature and Culture in Animal-Human Relations and Modern Surgery." History and Philosophy of the Life Sciences 31 (2009): $321-54$.

Schrepfer, Susan and Phillip Scranton (eds.) Industrializing Organisms: Introducing Evolutionary History. London: Routledge, 2003.

Schwabe, Calvin. Veterinary Medicine and Human Health. 3rd rev. edn. London: Williams \& Wilkins, 1984.

Shaw, D.G. (ed.). "Does History Need Animals?" History and Theory 52 (2013a): 45-67.

Shaw, G. "A Way with Animals." History and Theory 52 (2013b): 1-12.

Sivasundaram, Sujit. "Imperial Transgressions: The Animal and Human in the Idea of Race." Comparative Studies of South Asia, Africa and the Middle East 35 (2015): 156-172.

Swart, Sandra. "'But Where's the Bloody Horse?' Textuality and Corporeality in the 'Animal Turn." Journal of Literary Studies 23 (2007): 271-92.

Swart, Sandra. "Zombie Zoology: History and Reanimating Extinct Animals." In The Historical Animal, edited by Susan Nance, 54-71. New York: Syracuse University Press, 2015.

Taylor, Nik and Richard Twine (eds.). The Rise of Critical Animal Studies. From the Margins to the Centre. Abingdon: Routledge, 2014.

Thomas, Keith. Man and the Natural World: Changing Attitudes in England, 1500-1800. London: Penguin Books, 1983.

Todes, Daniel. "Pavlov's Physiology Factory." Isis 88 (1997): 205-46.

Tortorici, Zeb. "Animal Archive Stories: Species Anxieties in the Mexican National Archive." In The Historical Animal, edited by Susan Nance, 75-98. New York: Syracuse University Press, 2015.

Vandersommers, Dan. "The 'Animal Turn' in History." American Historical Association Blog. Accessed 19 February 2017. http://blog.historians. org/2016/11/animal-turn-history/.

Warner, J.H. "The Uses of Patient Records by Historians - Patterns, Possibilities and Perplexities." Health \& History 1 (1999): 101-11.

Wolfe, C. (ed.). Zoontologies: The Questions of the Animal. Minneapolis: University of Minnesota Press, 2003.

Woods, Abigail. "Animals and Disease." In Routledge History of Disease, edited by Mark Jackson, 147-64. London: Routledge, 2016.

Woods, Abigail. "Animals in Surgery." In Handbook of the History of Surgery, edited by Thomas Schlich, forthcoming. Basingstoke: Palgrave Macmillan, $2017 \mathrm{a}$. 
Woods, Abigail. "Animals in the History of Human and Veterinary Medicine." In Routledge Companion to Animal-Human History, edited by Hilda Kean and Phillip Howell. London: Routledge, 2017b.

Woods, Abigail. "From One medicine to Two: The Evolving Relationship between Human and Veterinary Medicine in England, 1791-1835." Bulletin of the History of Medicine 91 (2017c), 494-523.

Woods, Abigail and Michael Bresalier, "One Health, Many Histories." Veterinary Record 174 (2014), 650-4.

Zinsstag, J., E. Schelling, D. Waltner-Toews and M. Tannera. "From 'One Medicine' to 'One Health' and Systemic Approaches to Health and Wellbeing." Preventive Veterinary Medicine 101 (2011): 148-56.

Open Access This chapter is licensed under the terms of the Creative Commons Attribution 4.0 International License (http://creativecommons. org/licenses/by/4.0/), which permits use, sharing, adaptation, distribution and reproduction in any medium or format, as long as you give appropriate credit to the original author(s) and the source, provide a link to the Creative Commons license and indicate if changes were made.

The images or other third party material in this chapter are included in the chapter's Creative Commons license, unless indicated otherwise in a credit line to the material. If material is not included in the chapter's Creative Commons license and your intended use is not permitted by statutory regulation or exceeds the permitted use, you will need to obtain permission directly from the copyright holder.

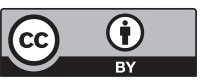

